\title{
International Cultural Heritage Law (2020)
}

\author{
Flavia Zorzi Giustiniani*
}

The Impact of the coviD-19 Pandemic on the Cultural Sector and the Public Policy Response

The COVID-19 pandemic had a deep impact also on the world's cultural heritage, affecting inter alia the following aspects: heritage site conservation, heritage maintenance, heritage tourism, museum operations, and health of heritage professionals. The systemic disruption triggered by the COVID-19 crisis on the cultural sector was the object of the 'Online Meeting of Ministers of Culture - Impact of the CoviD-19 Pandemic on the Cultural Sector and the Public Policy Response', which was convened by UNesco on 22 April 2020. The Meeting, building on the dialogue initiated by the Organization at the Forum of Ministers of Culture in November $2019,{ }^{1}$ brought together over 130 ministers of culture from all over the globe. It represented a call to action from UNESCO's Member States, highlighting the central role of culture in any society as well as its economic significance, being a source of economic development and employment. The participating ministers discussed the impact of the crisis on their respective cultural sectors as well as the different policies and measures envisaged at the national level, on the one hand, to mitigate such impact and on the other hand to support both the recovery and the resilience of the cultural sector.

The Meeting represented a veritable mass mobilization and was the occasion for UNESCO's Member States to reaffirm the crucial importance of culture for the adaptation and transformation of societies. ${ }^{2}$ The support measures undertaken at the national level showed States' primary responsibility to invest in culture and, in turn, culture's role in economic development and as an example of more resilient and inclusive economic models. ${ }^{3}$ Furthermore,

Associate Professor of European Union Law, Link Campus University.

1 See <https://en.unesco.org/events/forum-ministers-culture> last accessed (as any subsequent URL) on 25 June 2021.

2 See the 'Report of the Online Meeting of Ministers of Culture: Impact of the Covid-19 Pandemic on the Cultural Sector and the Public Policy Response' (22 April 2020) available at $<$ https://unesdoc.unesco.org/ark:/48223/pfoooo3736o1>.

3 Ibid. 
the participating ministers demonstrated their engagement in international cooperation and solidarity, and encouraged financial institutions to aid States' efforts through more significant investments in the cultural sector. ${ }^{4}$ Finally, with the mutual sharing of national perspectives, Member States also outlined priority areas for the future of the cultural sector, while UNESCO underlined its continuous support toward States' action in the areas of reflection, methodology and public policy in order to better anchor cultural policies in the 2030 Agenda for Sustainable Development. ${ }^{5}$

\section{Establishment of the United Nations Inter Agency Issue-Based Coalition (IBC) on Environment and Climate Change for Europe and Central Asia}

On 20 March, at the Regional UN System special session, the United Nations Inter Agency Issue-based Coalition (IBC) on Environment and Climate Change for Europe and Central Asia was established. This IBC, composed of $18 \mathrm{UN}$ agencies, ${ }^{6}$ is led by UNEsco together with the UN Environment Programme (UNEP) and the UN Economic Commission for Europe (UNECE). It is meant primarily to support Resident Coordinators (RCs) and UN Country Teams (UNCTs) in strengthening environmental and climate change governance, improving environmental management and climate change mitigation and adaptation, and promoting sustainable management of natural resources. Since its creation, three subregional consultations were held with RCs and unCTs from Central Asia, South-Eastern Europe, Eastern Europe, Caucasus, and Turkey. These consultations led to the creation of eleven thematic task teams, among which two are dedicated to climate change, disaster risk reduction, socio-economic assessments and post-pandemic recovery strategies. For 2021, the task team on climate change and disaster risk reduction envisages a policy brief on integrating Disaster Risk Reduction and Climate Change Adaptation and a dedicated webinar.

4 Ibid., 31.

5 Ibid.

6 The Coalition is open to all UN agencies, funds and programmes. At present its members are the following ones: FAO, ILO, IOM, ITU, OHCHR, UN Habitat, UN Women, UNDP, UNDRR, UNECE, UNEP, UNESCO, UNFCCC, UNICEF, UNOPS, WFP, WHO and WMO. 

on Intangible Cultural Heritage

The 14th annual meeting of the South-East European Experts Network on Intangible Cultural Heritage took place on 26 June 2020, in a virtual modality due to the pandemic, and was focused on Intangible Cultural Heritage (ICH) in emergencies and on responses to CoviD-19. ${ }^{7}$ The Network was established in 2007 by the UNESCO's Regional Bureau for Science and Culture in Europe with the objective to support the implementation of the 2003 Convention for the Safeguarding of the Intangible Cultural Heritage at the regional level. The Network's annual meetings contribute to share knowledge and good practices on national measures to implement the Convention, as well as to develop regional and cross-border cooperation. The 14th annual meeting was organized by UNESCO (Regional Bureau for Science and Culture in Europe, in cooperation with the Culture Sector/Living Heritage Entity), with the support of the Regional Centre for the Safeguarding of Intangible Cultural Heritage in South-East Europe. Notably, for the first time, the annual meeting brought together experts representing ICH national authorities with the UNESCOtrained facilitators from the countries concerned.

The active role that ICH can play in emergencies as a tool for recovery and resilience has been addressed by the Intergovernmental Committee for the safeguarding of the intangible cultural heritage since 2016. ${ }^{8}$ Last year the Covid crisis clearly added another layer of complexity and was particularly challenging for some South-Eastern European countries that were also hit at the same by a natural disaster. ${ }^{9}$ In this context, the meeting, which was attended by 64 participants of different backgrounds, was the occasion to share experiences on Covid-19's impact on ICH as well as on the variety of initiatives and responses developed by ICH practitioners and bearers to address the same pandemic. ${ }^{10}$

7 See $\quad<$ https://en.unesco.org/news/addressing-questions-intangible-cultural-heritage-and -resilience-times-crisis $>$.

8 See Intergovernmental Committee for the Safeguarding of the Intangible Cultural Heritage, Eleventh Session, ITH/16/11.COM/15, Paris, 31 October 2016, paras. 10-11.

$9 \quad$ Notably the earthquakes that struck Albania and Croatia respectively in 2019 and 2020.

10 See 14th Annual Meeting of the South-East European Experts Network on Intangible Cultural Heritage - 'Addressing questions of ICH and resilience in times of crisis' (26 June 2020) Report, IV. 